\title{
Social disparities, health risk behaviors, and cancer
}

\author{
Stefania Rametta', Giuseppe Grosso², Fabio Galvano², Antonio Mistretta ${ }^{1 *}$, Stefano Marventano ${ }^{1}$, Francesca Nolfo ${ }^{1}$, \\ Silvio Buscemi ${ }^{3}$, Santi Gangi ${ }^{4}$, Francesco Basile ${ }^{4}$, Antonio Biondi ${ }^{4}$ \\ From 26th National Congress of the Italian Society of Geriatric Surgery \\ Naples, Italy. 19-22 June 2013
}

\begin{abstract}
Background: Overall cancer incidence rates decreased in the most recent time period in both men and women, largely due to improvements in surgical therapeutic approaches (tertiary prevention) and screening programs (secondary prevention), but differences in cancer incidence and survival according to socioeconomic status are documented worldwide. Health risk behaviors, defined as habits or practices that increase an individual's likelihood of harmful health outcomes, are thought to mediate such inequalities.

Discussion: Obesity has been related with increased cancer incidence and mortality due to imbalance of leptin and adiponectin which are connected to activation of PI3K, MAPK, and STAT3 pathways and decreasing insulin/ insulin-like growth factor (IGF)-1 and mTOR signaling via activation of 5 AMP-activated protein kinase (AMPK), respectively. Physical activity has been associated to prevent cancer by the aforementioned obesity-related mechanisms, but also increasing level of circulating vitamin $D$, which has been related to lower risk of several cancers, and increasing prostaglandin F2a and reducing prostaglandin E2, which are both related with cancer prevention and promotion, respectively. A large number of different substances may induce themselves a direct cytotoxicity and mutagenic action on cells by smoking, whereas alcohol promote immune suppression, the delay of DNA repair, inhibition of the detoxification of carcinogens, the production of acetaldehyde, and the contribution to abnormal DNA methylation. The combined smoking and alcohol drinking habits have been shown to increase cancer risk by smoke action of increasing the acetaldehyde burden following alcohol consumption and alcohol action of enhancing the activation of various procarcinogens contained in tobacco smoke.
\end{abstract}

Conclusions: Interventions at the social level may be done to increase awareness about cancer risks and promote changing in unhealthy behaviors.

\section{Background}

Cancer is a leading cause of death worldwide, accounting for 7.6 million deaths (around 13\% of all deaths) [1]. Overall cancer incidence rates decreased in the most recent time period in both men and women, largely due to decreases in the 3 major cancer sites in men (lung, prostate, and colorectum) and 2 major cancer sites in women (breast and colorectum) [2]. It has been documented that a decrease has been reached also in mortality rates, mostly

\footnotetext{
* Correspondence: anmistr@unict.it

'Department "G. F. Ingrassia" Section of Hygiene and Public Health,

University of Catania, Catania, Italy

Full list of author information is available at the end of the article
}

due to improvements in surgical therapeutic approaches [3-5]. However, different outcomes have been reported due to non-modifiable factors such age [6,7] and increased cancer mortality due to modifiable factors, such as the socioeconomic status, has been well documented worldwide, irrespectively of national health-care system [8-10]. Social disparities in cancer survival are multidimensional and may depend on factors related to the public health care organization [11]. These factors may regard screening, diagnosis conditions, access to specialized care, treatment or follow-up modalities, and they vary according to the health care systems [12]. In countries where the insurance status is crucial for access and continuity of care,
C Biomed Central

C 2013 Rametta et al; licensee BioMed Central Ltd. This is an open access article distributed under the terms of the Creative Commons Attribution License (http://creativecommons.org/licenses/by/2.0), which permits unrestricted use, distribution, and reproduction in any medium, provided the original work is properly cited. 
increased financial resources may support patients to better manage the disease $[13,14]$. Many evidences have demonstrated inequalities by socioeconomic status and race. Several studies have reported inequalities at different levels, for instance in delay of hospitalization or advanced cancer stage at diagnosis for disadvantaged groups $[15,16]$. Similar trends have been reported regarding survival of cancer patients, evidencing inequalities among lower socioeconomic classes and economically disadvantaged race and ethnicity groups $[17,18]$. Cultural disparities may depend on a different access to health information. In example, higher education has been associated with increased internet use and high eHealth literacy which is related to have increased knowledge and previous screening practice related to colorectal cancer compared to those with low eHealth literacy [19]. A higher education and knowledge about colorectal cancer related information has been also related with an increased acceptance of colorectal cancer screening programs [20]. On the other hand, in countries with equal access to health-care facilities, a direct economic hindrance in seeking medical health care cannot be relevant, because health-care facilities are tax-financed. Thus, socioeconomic and cultural status may act by psychosocial pathways. More acculturated people may have higher knowledge about healthrelated topics, be more aware of their symptoms and communicate better with health staff than low-cultural people $[21,22]$. Health risk behaviors are defined as habits or practices that increase an individual's likelihood of harmful health outcomes. They are thought to explain, at least in part, many social inequalities in health status of populations. It has been reported that health risk behaviors, including diet, physical activity, and smoking, explain the higher frequencies of several cancers and mortality among those of lower socio-economic status [23]. On the other hand, although many of these factors are modifiable causes of cancer, it is challenging to plan interventions acting on the specific associations between them and cancer over a lifetime, due to the long latent period for cancer development and its complex pathogenesis. Thus, the only possibility to prevent cancer is to increase awareness in people regarding health-related behaviors in order to establish life-long habits that may decrease the risk of developing malignancies. As most of cancerpromoting factors are related with the social status of one person, we will discuss of the main well-recognized cause of cancer which may mediate social and cultural effects on cancer developing and survival.

\section{Obesity}

Obesity has dramatically increased during the last few decades both in developed and now also in developing countries, contributing to the global rising of cardiovascular diseases [24]. Nowadays, it has been estimated that overweight population increased in European countries ranging between $8 \%$ and $40 \%$ in men and between $5 \%$ and $53 \%$ in women [25], whereas in the United States reached the $66 \%$ of adults with a BMI $>25 \mathrm{~kg} / \mathrm{m} 2$ and half of those have a BMI of $>30 \mathrm{~kg} / \mathrm{m} 2$ [26]. The fast rise of obesity in Western countries cannot be related with a genetic mutation due to the high rapidity of the phenomenon. Conversely, over the past few decades, the transformation of the modern environment leaded to changes in diet and physical activity.

Obesity has been widely associated with non-communicable diseases, such as cardiovascular diseases (heart disease and stroke), diabetes, osteoarthritis and musculoskeletal disorders, fatty liver, gall stones, psychological disorders, and psychosocial problems [27] as well as it has been also related to increased mortality [28]. Obesity has been also associated to a higher incidence of many cancers, including cancers of the endometrium, kidney, gallbladder (in women), breast, colon, and esophagus [29], and increased cancer-related mortality [30]. An indirect association between obesity and diet quality may explain the increased risk of cancer [30,31], since the lacking of healthy nutrients may occurs in subjects consuming low-quality diet [31-36]. On the other hand, despite the biological mechanisms explaining the direct relationship between obesity and cancer are still unclear, several hypotheses have been proposed [37]. As adipose tissue is an endocrine organ that produces and secretes polypeptide hormones (i.e., leptin and adiponectin), it has been hypothesized that imbalance of production of such hormones may be involved in cancer development [38,39]. Specifically, a pro-carcinogenic effect of leptin has been demonstrated by activation of PI3K, MAPK, and STAT3 pathways [40-42] whereas adiponectin may exert anticancer effects by decreasing insulin/insulinlike growth factor (IGF)-1 and mTOR signaling via activation of 5 AMP-activated protein kinase (AMPK) and exerting anti-inflammatory actions via the inhibition of nuclear factor kappa-light-chain-enhancer of activated B cells $(\mathrm{NF}-\kappa \mathrm{B})$ [43]. Also steroid hormones, including estrogen, progesterone, androgens, and adrenal steroids are associated with adipose tissue [44] and may play a role on progression of several types of male and female cancer [45].

An inflammation theory for cancer development related to obesity has been also hypothesized. Indeed, the increased levels of proinflammatory cytokines and various interleukins related to body adiposity, may stimulate the activation of NF- $\kappa \mathrm{B}$ complex which may promote cancer development itself [46].

Hyperinsulinemia and elevated IGF-1 are related to the diabetic condition and the obese status. Both insulin and IGF-1 have been hypothesized to play a role on cancer promotion through the Akt/PI3K/mTOR cascade that promotes cell growth and proliferation $[47,48]$. On the contrary, caloric restriction induce the disruption of 
the Akt/PI3K/mTOR cascade at least in part via AMPK activation $[49,50]$ and is frequently associated with a decreased cancer incidence of breast cancer in humans and in animal models $[51,52]$. Interestingly, similar pathways are involved in cancer promotion and progression irrespectively of the primary cause, thus suggesting a possible target for therapy $[53,54]$.

Obesity has been related also to decreased survival in patients affected by several types of cancers $[55,56]$ although no study has elucidated the causal mechanism and there is currently no evidence that weight loss after diagnosis improves survival. Considerations regarding obese patients are focused on chemotherapy, radiotherapy, and surgical treatment [34]. Concerns of relative over(due to increased weight) or under-dosing (to avoid toxicity) of chemotherapy in the obese cancer patients have been reported [57]. Moreover, technical difficulties in positioning obese patients during radiotherapy may occur [58]. Finally, high BMI has been strongly, but not univocally, predictive of worse operative outcomes [59].

\section{Physical activity}

A protective association between physical activity and colon, breast, ovarian, lung, and renal cancers is supported by a number of review articles [60-67]. Similar effects have been demonstrated also in prolonging survival in cancer patients [68]. Unlike these consistently observed findings, the association with rectal cancer is still uncertain [69] maybe due to the different carcinogenic mechanisms related with the cancer location. Main hypothesized mechanisms include those aforementioned obesity-related such as decreased adipose tissue accumulation, decreased inflammation, reduced levels of insulin and IGF- 1 and modulated immune response [70]. Physical activity also increase level of circulating vitamin D [71], which has a direct anti-carcinogenic effect on colonic epithelial cells [72] and has been related to lower risk of colon, renal, and other cancers [73-75]. Moreover, the decreased bowel transit time induced by physical activity reduce the exposure of the colon to colonic contents, bile acids and other potential carcinogens [76]. Finally, physical activity has been also related to increased prostaglandin F2a [77] and reduced prostaglandin E2 [78] that are both related with cancer prevention and promotion, respectively [79].

\section{Smoking and alcohol drinking}

Several reports seem to demonstrate the detrimental effects of smoke on health, increasing risk of many cancers, including lung, laryngeal and pharyngeal, followed by upper digestive tract and oral cancers [80], as well as bladder [81] renal [82], breast [83], and colorectal cancers [84]. Despite the pathogenicity of tobacco smoking for pulmonary and urologic cancers appears well understood, doubts on the precise biological mechanisms on colorectal cancer promotion and progression still exist. The way by which cigarette smoking may induce lung malignancy includes a large number of different substances, most of them currently unknown, that may induce themselves a direct cytotoxicity and mutagenic action on lung epithelial cells by means of generation of DNA mutations, epigenetic events, epithelial cell to mesenchymal cell transformations, as well as by chronic cell damage $[85,86]$. Regarding low digestive tract cancers, epidemiological data revealed that a long period of exposure is required to increase risk of colon cancer [87]. It has been hypothesized that the possibility of proto-oncogene mutation in gastrointestinal mucosa cells may be associated with tobacco smoking-induced cancers through the formation of unfavorable DNA adducts [88]. Moreover, the association of smoking with rectal cancer seems to be stronger than with colon $[87,89]$.

Alcohol has been reported to cause nearly $4 \%$ of the global cancer burden [90], and chronic consumption has been associated with cancers of the oral cavity, larynx, pharynx, esophagus, liver, colon, rectum, and breast [91]. Some meta-analyses of case-control [92] and cohort studies [93-95] concluded that a daily alcohol intake of 25-30 g or more is significantly associated with increased risk of colon and rectal cancer, suggesting a linear dose-response relationship. The mechanisms hypothesized to play a role in cancer promotion involve the immune suppression, the delay of DNA repair, the induction of cytochrome P-450 enzymes that inhibit the detoxification of carcinogens (including nitrosamine), the changes in bile acid composition, the production of acetaldehyde (a known carcinogen implicated in colorectal carcinogenesis), and the contribution to abnormal DNA methylation [96,97]. Moreover, alcohol may enhance the penetration of other carcinogenic molecules into mucosal cells by acting as a solvent and may stimulate regenerative cell growth by various cytotoxic mechanisms including the excess production of oxygen free radicals [97].

The combined smoking and alcohol drinking habits have been shown to be detrimental for health and notably increase cancer risk by smoke action of increasing the acetaldehyde burden following alcohol consumption and alcohol action of enhancing the activation of various procarcinogens contained in tobacco smoke due to increased metabolic activation by an induced cytochrome P450-2E1dependent microsomal biotransformation system in the mucosa of the upper digestive tract and the liver [98].

\section{Recommendations and conclusions}

The most recognized interventions on cancer prevention regard secondary prevention, such as screening programs. These interventions aim to diagnose the malignancies at an early stage and to treat these lesions before spread occurs. On the other hand, they do not interfere 
with factors which may play a role in the genesis and promotion of the disease. Primary prevention may reduce the exposure to cancer-promoting environmental and behavioral influences [99].

A series of intervention through public health policy can be made in order to decrease cancer risk among general population. Regarding smoking habit, a six-point intervention list has been developed by the World Health Organization and focus on the following main features: monitor tobacco use and prevention policies; protect people from tobacco smoke; offer help to quit tobacco use; warn about the dangers of tobacco; enforce bans on tobacco advertising, promotion, and sponsorship; and raise taxes on tobacco [100]. Public policy options for alcohol control include, as well as with tobacco control, availability and taxation, for example by reducing retail hours and density of alcohol outlets, which has been reported to reduce sales and consumption [101-103]. Moreover, interventions at the social level may be done to discourage consumption. Public health efforts should be made in order to ameliorate the environmental context for healthy eating by providing easier access and price incentives for healthy foods such as fruit and vegetables. Interventions on food advertising have been demonstrated to be effective in increase diet quality and reduce obesity rates [104]. Moreover, education on maximizing opportunities for physical activity, such as encouraging stair use over elevators, may help people to maintain a healthy weight.

\section{Competing interests}

The authors declare that they have no competing interests.

\section{Authors' contributions}

SR: conception and design, drafting the manuscript; GG, AM, SM, FN: drafting the manuscript; $S B, F G, F B, S G, A B$ : critical revision, given final approval of the version to be published.

\section{Acknowledgements}

Giuseppe Grosso was supported by the International Ph.D. Program in Neuropharmacology, University of Catania Medical School, Catania, Italy. The funders had no role in the study design, data collection and analysis, decision to publish, or preparation of the manuscript.

\section{Declarations}

Funding for this article came from University funds.

This article has been published as part of BMC Surgery Volume 13 Supplement 2, 2013: Proceedings from the 26th National Congress of the Italian Society of Geriatric Surgery. The full contents of the supplement are available online at http://www.biomedcentral.com/bmcsurg/supplements/13/ S2

\section{Authors' details}

'Department "G. F. Ingrassia" Section of Hygiene and Public Health, University of Catania, Catania, Italy. ${ }^{2}$ Department of Drug Sciences, Section of Biochemistry, University of Catania, Catania, Italy. ${ }^{3}$ Department of Internal Medicine, University of Palermo, Palermo, Italy. ${ }^{4}$ Department of General Surgery, Section of General Surgery and Oncology, University Medical School of Catania, Italy.

Published: 8 October 2013
References

1. Ferlay J, Shin HR, Bray F, Forman D, Mathers C, Parkin DM: Cancer Incidence and Mortality Worldwide: IARC CancerBase. Lione: International Agency for Research on Cancer 2010.

2. Jemal A, Siegel $R, X u$ J, Ward E: Cancer statistics, 2010. CA: a cancer journal for clinicians 2010, 60(5):277-300.

3. Biondi A, Grosso G, Mistretta A, Marventano S, Toscano C, Gruttadauria S, Basile F: Laparoscopic-assisted versus open surgery for colorectal cancer: short- and long-term outcomes comparison. Journal of laparoendoscopic \& advanced surgical techniques Part A 2013, 23(1):1-7.

4. Cantore F, Colombo EM, Giuseppe MD, Biondi A, Rausei S, Dionigi G, Rovera F, Boni L, Dionigi R: Single access cholecystectomy using standard laparoscopic instruments. Updates in surgery 2011, 63(1):31-34.

5. Biondi A, Tropea A, Basile F: Clinical rescue evaluation in laparoscopic surgery for hepatic metastases by colorectal cancer. Surgical laparoscopy, endoscopy \& percutaneous techniques 2010, 20(2):69-72.

6. Vacante M, D'Agata V, Motta M, Malaguarnera G, Biondi A, Basile F, Malaguarnera M, Gagliano C, Drago F, Salamone S: Centenarians and supercentenarians: a black swan. Emerging social, medical and surgical problems. BMC surgery 2012, 12(Suppl 1):S36.

7. Grosso G, Biondi A, Marventano S, Mistretta A, Calabrese G, Basile F: Major postoperative complications and survival for colon cancer elderly patients. BMC surgery 2012, 12(Suppl 1):S20.

8. Maskarinec G, Sen C, Koga K, Conroy SM: Ethnic differences in breast cancer survival: status and determinants. Womens Health (Lond Engl) 2011, 7(6):677-687

9. Obertova Z, Brown C, Holmes M, Lawrenson R: Prostate cancer incidence and mortality in rural men-a systematic review of the literature. Rural and remote health 2012, 12(2):2039.

10. Slatore CG, Au DH, Gould MK: An official American Thoracic Society systematic review: insurance status and disparities in lung cancer practices and outcomes. American journal of respiratory and critical care medicine 2010, 182(9):1195-1205.

11. Merletti F, Galassi C, Spadea T: The socioeconomic determinants of cancer. Environmental health: a global access science source 2011, 10(Suppl 1):S7.

12. Woods LM, Rachet B, Coleman MP: Origins of socio-economic inequalities in cancer survival: a review. Annals of oncology : official journal of the European Society for Medical Oncology / ESMO 2006, 17(1):5-19.

13. Halpern MT, Pavluck AL, Ko CY, Ward EM: Factors associated with colon cancer stage at diagnosis. Digestive diseases and sciences 2009, 54(12):2680-2693.

14. Ross JS, Bradley EH, Busch SH: Use of health care services by lowerincome and higher-income uninsured adults. JAMA : the journal of the American Medical Association 2006, 295:2027-2036.

15. Halpern MT, Holden DJ: Disparities in timeliness of care for U.S. Medicare patients diagnosed with cancer. Curr Oncol 2012, 19(6):e404-413.

16. Chornokur G, Dalton K, Borysova ME, Kumar NB: Disparities at presentation, diagnosis, treatment, and survival in African American men, affected by prostate cancer. The Prostate 2011, 71(9):985-997.

17. Wassira LN, Pinheiro PS, Symanowski J, Hansen A: Racial-ethnic colorectal cancer survival disparities in the mountain west region: the case of Blacks compared to Whites. Ethnicity \& disease 2013, 23(1):103-109.

18. Lam VK, Lu AT, Kouzminova N, Lin AY: Characteristics of colorectal cancer survival in an urban county hospital. Journal of gastrointestinal cancer 2013, 44(1):68-72.

19. Mitsutake S, Shibata A, Ishii K, Oka K: Association of eHealth literacy with colorectal cancer knowledge and screening practice among internet users in Japan. Journal of medical Internet research 2012, 14(6):e153.

20. Lin YH, Kao CC: Factors Influencing Colorectal Cancer Screening in Rural Southern Taiwan. Cancer nursing 2012.

21. Jones SC, Johnson K: Women's awareness of cancer symptoms: a review of the literature. Womens Health (Lond Engl) 2012, 8(5):579-591.

22. Viswanath $K$, Nagler RH, Bigman-Galimore CA, McCauley MP, Jung M, Ramanadhan S: The communications revolution and health inequalities in the 21st century: implications for cancer control. Cancer epidemiology, biomarkers \& prevention : a publication of the American Association for Cancer Research, cosponsored by the American Society of Preventive Oncology 2012, 21(10):1701-1708.

23. Weyers S, Dragano N, Richter M, Bosma H: How does socio economic position link to health behaviour? Sociological pathways and perspectives for health promotion. Glob Health Promot 2010, 17(2):25-33. 
24. Kjeldsen SE, Naditch-Brule L, Perlini S, Zidek W, Farsang C: Increased prevalence of metabolic syndrome in uncontrolled hypertension across Europe: the Global Cardiometabolic Risk Profile in Patients with hypertension disease survey. Journal of hypertension 2008, 26(10):2064-2070.

25. Haftenberger M, Lahmann PH, Panico S, Gonzalez CA, Seidell JC, Boeing $H_{\text {, }}$ Giurdanella MC, Krogh V, Bueno-de-Mesquita HB, Peeters PH, et al: Overweight, obesity and fat distribution in 50- to 64-year-old participants in the European Prospective Investigation into Cancer and Nutrition (EPIC). Public health nutrition 2002, 5(6B):1147-1162.

26. Flegal KM, Carroll MD, Kit BK, Ogden CL: Prevalence of obesity and trends in the distribution of body mass index among US adults, 1999-2010. JAMA : the journal of the American Medical Association 2012, 307(5):491-497.

27. Rosse LM, Rossen EA: Obesity 101 New York: Springer Publishing Co; 2012.

28. Berrington de Gonzalez A, Hartge P, Cerhan JR, Flint AJ, Hannan L, MacInnis RJ, Moore SC, Tobias GS, Anton-Culver H, Freeman LB, et al: Bodymass index and mortality among 1.46 million white adults. The New England journal of medicine 2010, 363(23):2211-2219.

29. Calle EE, Rodriguez C, Walker-Thurmond K, Thun MJ: Overweight, obesity, and mortality from cancer in a prospectively studied cohort of U.S. adults. The New England journal of medicine 2003, 348(17):1625-1638.

30. Kaidar-Person O, Bar-Sela G, Person B: The two major epidemics of the twenty-first century: obesity and cancer. Obesity surgery 2011, 21(11):1792-1797.

31. Biondi A, Fisichella R, Fiorica F, Malaguarnera M, Basile F: Food mutagen and gastrointestinal cancer. European review for medical and pharmacological sciences 2012, 16(9):1280-1282.

32. Berretta M, Lleshi A, Fisichella R, Berretta S, Basile F, Li Volti G, Bolognese A, Biondi A, De Paoli $P$, Tirelli $U$, et al: The role of nutrition in the development of esophageal cancer: what do we know? Front Biosci (Elite Ed) 2012, 4:351-357.

33. Grosso G, Bei R, Mistretta A, Marventano S, Calabrese G, Masuelli L, Giganti MG, Modesti A, Galvano F, Gazzolo D: Effects of Vitamin C on health: a review of evidence. Frontiers in bioscience 2013, 18:1017-29.

34. Vitale DC, Piazza C, Melilli B, Drago F, Salomone S: Isoflavones: estrogenic activity, biological effect and bioavailability. European journal of drug metabolism and pharmacokinetics 2013, 38(1):15-25.

35. Li Volti G, Salomone S, Sorrenti V, Mangiameli A, Urso V, Siarkos I, Galvano F, Salamone F: Effect of silibinin on endothelial dysfunction and ADMA levels in obese diabetic mice. Cardiovascular diabetology 2011, $10: 62$

36. Grosso G, Galvano F, Mistretta A, Marventano S, Nolfo F, Calabrese G, Buscemi S, Drago F, Veronesi U, Scuderi A: Red orange: experimental models and epidemiological evidence of its benefits on human health. Oxidative medicine and cellular longevity 2013, 2013:157240.

37. Vucenik I, Stains JP: Obesity and cancer risk: evidence, mechanisms, and recommendations. Annals of the New York Academy of Sciences 2012, 1271:37-43.

38. Drew JE: Molecular mechanisms linking adipokines to obesity-related colon cancer: focus on leptin. The Proceedings of the Nutrition Society 2012, 71(1):175-180.

39. Kershaw EE, Flier JS: Adipose tissue as an endocrine organ. The Journal of clinical endocrinology and metabolism 2004, 89(6):2548-2556.

40. Chen J: Multiple signal pathways in obesity-associated cancer. Obesity reviews : an official journal of the International Association for the Study of Obesity 2011, 12(12):1063-1070.

41. Gao J, Tian J, LV Y, Shi F, Kong F, Shi H, Zhao L: Leptin induces functional activation of cyclooxygenase-2 through JAK2/STAT3, MAPK/ERK, and $\mathrm{PI}$ KK/AKT pathways in human endometrial cancer cells. Cancer science 2009, 100(3):389-395

42. Jaffe T, Schwartz B: Leptin promotes motility and invasiveness in human colon cancer cells by activating multiple signal-transduction pathways. International journal of cancer Journal international du cancer 2008, 123(11):2543-2556

43. Dalamaga M, Diakopoulos KN, Mantzoros CS: The role of adiponectin in cancer: a review of current evidence. Endocrine reviews 2012 , 33(4):547-594.

44. Kaaks R, Lukanova A, Kurzer MS: Obesity, endogenous hormones, and endometrial cancer risk: a synthetic review. Cancer epidemiology, biomarkers \& prevention : a publication of the American Association for
Cancer Research, cosponsored by the American Society of Preventive Oncology 2002, 11(12):1531-1543.

45. Hursting SD, Lashinger LM, Wheatley KW, Rogers CJ, Colbert LH, Nunez NP, Perkins SN: Reducing the weight of cancer: mechanistic targets for breaking the obesity-carcinogenesis link. Best practice \& research Clinical endocrinology \& metabolism 2008, 22(4):659-669.

46. Harvey $A E$, Lashinger LM, Hursting SD: The growing challenge of obesity and cancer: an inflammatory issue. Annals of the New York Academy of Sciences 2011, 1229:45-52.

47. Renehan AG, Frystyk J, Flyvbjerg A: Obesity and cancer risk: the role of the insulin-IGF axis. Trends in endocrinology and metabolism: TEM 2006, 17(8):328-336

48. Dann SG, Selvaraj A, Thomas G: mTOR Complex1-S6K1 signaling: at the crossroads of obesity, diabetes and cancer. Trends in molecular medicine 2007, 13(6):252-259.

49. Moore T, Beltran L, Carbajal S, Strom S, Traag J, Hursting SD, DiGiovanni J: Dietary energy balance modulates signaling through the Akt/ mammalian target of rapamycin pathways in multiple epithelial tissues. Cancer Prev Res (Phila) 2008, 1(1):65-76.

50. Jiang $W$, Zhu Z, Thompson HJ: Dietary energy restriction modulates the activity of AMP-activated protein kinase, Akt, and mammalian target of rapamycin in mammary carcinomas, mammary gland, and liver. Cancer research 2008, 68(13):5492-5499.

51. Fierz Y, Novosyadlyy R, Vijayakumar A, Yakar S, LeRoith D: Mammalian target of rapamycin inhibition abrogates insulin-mediated mammary tumor progression in type 2 diabetes. Endocrine-related cancer 2010, 17(4):941-951.

52. Novosyadlyy R, Lann DE, Vijayakumar A, Rowzee A, Lazzarino DA, Fierz Y, Carboni JM, Gottardis MM, Pennisi PA, Molinolo AA, et al: Insulin-mediated acceleration of breast cancer development and progression in a nonobese model of type 2 diabetes. Cancer research 2010, 70(2):741-751.

53. Ragusa M, Statello L, Maugeri M, Majorana A, Barbagallo D, Salito L, Sammito M, Santonocito M, Angelica R, Cavallaro A, et al: Specific alterations of the microRNA transcriptome and global network structure in colorectal cancer after treatment with MAPK/ERK inhibitors. J Mol Med (Berl) 2012, 90(12):1421-1438

54. Ragusa M, Majorana A, Statello L, Maugeri M, Salito L, Barbagallo D, Guglielmino MR, Duro LR, Angelica R, Caltabiano R, et al: Specific alterations of microRNA transcriptome and global network structure in colorectal carcinoma after cetuximab treatment. Molecular cancer therapeutics 2010, 9(12):3396-3409.

55. Protani M, Coory M, Martin JH: Effect of obesity on survival of women with breast cancer: systematic review and meta-analysis. Breast cancer research and treatment 2010, 123(3):627-635.

56. Protani MM, Nagle CM, Webb PM: Obesity and ovarian cancer survival: a systematic review and meta-analysis. Cancer Prev Res (Phila) 2012, 5(7):901-910.

57. Griggs JJ, Sorbero ME, Lyman GH: Undertreatment of obese women receiving breast cancer chemotherapy. Archives of internal medicine 2005, 165(11):1267-1273.

58. Wong JR, Gao Z, Merrick S, Wilson P, Uematsu M, Woo K, Cheng CW: Potential for higher treatment failure in obese patients: correlation of elevated body mass index and increased daily prostate deviations from the radiation beam isocenters in an analysis of 1,465 computed tomographic images. International journal of radiation oncology, biology, physics 2009, 75(1):49-55.

59. Healy LA, Ryan AM, Sutton E, Younger K, Mehigan B, Stephens R, Reynolds JV: Impact of obesity on surgical and oncological outcomes in the management of colorectal cancer. International journal of colorectal disease 2010, 25(11):1293-1299.

60. Spence RR, Heesch KC, Brown WJ: A systematic review of the association between physical activity and colorectal cancer risk. Scandinavian journal of medicine \& science in sports 2009, 19(6):764-781.

61. Wolin KY, Yan Y, Colditz GA, Lee IM: Physical activity and colon cancer prevention: a meta-analysis. British journal of cancer 2009, 100(4):611-616.

62. Wu Y, Zhang D, Kang S: Physical activity and risk of breast cancer: a meta-analysis of prospective studies. Breast cancer research and treatment 2013, 137(3):869-882.

63. Olsen CM, Green AC, Whiteman DC, Sadeghi S, Kolahdooz F, Webb PM: Obesity and the risk of epithelial ovarian cancer: a systematic review and meta-analysis. Eur J Cancer 2007, 43(4):690-709. 
64. Buffart LM, Singh AS, van Loon EC, Vermeulen HI, Brug J, Chinapaw MJ: Physical activity and the risk of developing lung cancer among smokers: A meta-analysis. Journal of science and medicine in sport / Sports Medicine Australia 2013

65. Behrens G, Leitzmann MF: The association between physical activity and renal cancer: systematic review and meta-analysis. British journal of cancer 2013, 108(4):798-811.

66. Boyle T, Keegel T, Bull F, Heyworth J, Fritschi L: Physical activity and risks of proximal and distal colon cancers: a systematic review and metaanalysis. Journal of the National Cancer Institute 2012, 104(20):1548-1561.

67. Sun JY, Shi L, Gao XD, Xu SF: Physical activity and risk of lung cancer: a meta-analysis of prospective cohort studies. Asian Pac J Cancer Prev 2012, 13(7):3143-3147.

68. Ibrahim EM, Al-Homaidh A: Physical activity and survival after breast cancer diagnosis: meta-analysis of published studies. Med Oncol 2011, 28(3):753-765.

69. Pham NM, Mizoue T, Tanaka K, Tsuji I, Tamakoshi A, Matsuo K, Ito H, Wakai K, Nagata C, Sasazuki S, et al: Physical activity and colorectal cancer risk: an evaluation based on a systematic review of epidemiologic evidence among the Japanese population. Japanese journal of clinical oncology 2012, 42(1):2-13.

70. Rogers CJ, Colbert LH, Greiner JW, Perkins SN, Hursting SD: Physical activity and cancer prevention : pathways and targets for intervention. Sports Med 2008, 38(4):271-296.

71. Scragg R, Camargo CA Jr: Frequency of leisure-time physical activity and serum 25-hydroxyvitamin D levels in the US population: results from the Third National Health and Nutrition Examination Survey. American journal of epidemiology 2008, 168(6):577-586, discussion 587-591.

72. Lamprecht SA, Lipkin M: Cellular mechanisms of calcium and vitamin D in the inhibition of colorectal carcinogenesis. Annals of the New York Academy of Sciences 2001, 952:73-87.

73. Joh HK, Giovannucci EL, Bertrand KA, Lim S, Cho E: Predicted Plasma 25Hydroxyvitamin D and Risk of Renal Cell Cancer. Journal of the National Cancer Institute 2013.

74. Touvier M, Chan DS, Lau R, Aune D, Vieira R, Greenwood DC, Kampman E, Riboli E, Hercberg S, Norat T: Meta-analyses of vitamin D intake, 25-hydroxyvitamin D status, vitamin D receptor polymorphisms, and colorectal cancer risk. Cancer epidemiology, biomarkers \& prevention : a publication of the American Association for Cancer Research, cosponsored by the American Society of Preventive Oncology 2011, 20(5):1003-1016.

75. Giovannucci E: Vitamin D and cancer incidence in the Harvard cohorts. Annals of epidemiology 2009, 19(2):84-88.

76. Cordain L, Latin RW, Behnke JJ: The effects of an aerobic running program on bowel transit time. The Journal of sports medicine and physical fitness 1986, 26(1):101-104.

77. Demers LM, Harrison TS, Halbert DR, Santen RJ: Effect of prolonged exercise on plasma prostaglandin levels. Prostaglandins and medicine 1981, 6(4):413-418.

78. Martinez ME, Heddens D, Earnest DL, Bogert CL, Roe D, Einspahr J, Marshall JR, Alberts DS: Physical activity, body mass index, and prostaglandin E2 levels in rectal mucosa. Journal of the National Cancer Institute 1999, 91(11):950-953.

79. Karmali RA: Review: prostaglandins and cancer. Prostaglandins and medicine 1980, 5(1):11-28.

80. Gandini S, Botteri E, lodice S, Boniol M, Lowenfels AB, Maisonneuve P, Boyle P: Tobacco smoking and cancer: a meta-analysis. International journal of cancer Journal international du cancer 2008, 122(1):155-164.

81. Hemelt M, Yamamoto $H$, Cheng KK, Zeegers MP: The effect of smoking on the male excess of bladder cancer: a meta-analysis and geographical analyses. International journal of cancer Journal international du cancer 2009, 124(2):412-419.

82. Hunt JD, van der Hel OL, McMillan GP, Boffetta P, Brennan P: Renal cell carcinoma in relation to cigarette smoking: meta-analysis of 24 studies. International journal of cancer Journal international du cancer 2005, 114(1):101-108.

83. Gaudet MM, Gapstur SM, Sun J, Diver WR, Hannan LM, Thun MJ: Active smoking and breast cancer risk: original cohort data and meta-analysis. Journal of the National Cancer Institute 2013, 105(8):515-525.

84. Raimondi S, Botteri E, lodice S, Lowenfels AB, Maisonneuve P: Genesmoking interaction on colorectal adenoma and cancer risk: review and meta-analysis. Mutation research 2009, 670(1):6-14.
85. Milara J, Cortijo J: Tobacco, inflammation, and respiratory tract cancer. Current pharmaceutical design 2012, 18(26):3901-3938.

86. Hecht SS: Lung carcinogenesis by tobacco smoke. International journal of cancer Journal international du cancer 2012, 131(12):2724-2732.

87. Giovannucci E: An updated review of the epidemiological evidence that cigarette smoking increases risk of colorectal cancer. Cancer epidemiology, biomarkers \& prevention : a publication of the American Association for Cancer Research, cosponsored by the American Society of Preventive Oncology 2001, 10(7):725-731.

88. Diggs DL, Huderson AC, Harris KL, Myers JN, Banks LD, Rekhadevi PV, Niaz MS, Ramesh A: Polycyclic aromatic hydrocarbons and digestive tract cancers: a perspective. Journal of environmental science and health Part C, Environmental carcinogenesis \& ecotoxicology reviews 2011, 29(4):324-357.

89. Mizoue T, Inoue M, Tanaka K, Tsuji I, Wakai K, Nagata C, Tsugane S: Tobacco smoking and colorectal cancer risk: an evaluation based on a systematic review of epidemiologic evidence among the Japanese population. Japanese journal of clinical oncology 2006, 36(1):25-39.

90. Boffetta P, Hashibe M, La Vecchia C, Zatonski W, Rehm J: The burden of cancer attributable to alcohol drinking. International journal of cancer Journal international du cancer 2006, 119(4):884-887.

91. Boffetta P, Hashibe M: Alcohol and cancer. The lancet oncology 2006, 7(2):149-156.

92. Fedirko V, Tramacere I, Bagnardi V, Rota M, Scotti L, Islami F, Negri E, Straif K, Romieu I, La Vecchia C, et al: Alcohol drinking and colorectal cancer risk: an overall and dose-response meta-analysis of published studies. Annals of oncology : official journal of the European Society for Medical Oncology / ESMO 2011, 22(9):1958-1972.

93. Moskal A, Norat T, Ferrari P, Riboli E: Alcohol intake and colorectal cancer risk: a dose-response meta-analysis of published cohort studies. International journal of cancer Journal international du cancer 2007 120(3):664-671.

94. Cho E, Smith-Warner SA, Ritz J, van den Brandt PA, Colditz GA, Folsom AR, Freudenheim JL, Giovannucci E, Goldbohm RA, Graham S, et al: Alcohol intake and colorectal cancer: a pooled analysis of 8 cohort studies. Annals of internal medicine 2004, 140(8):603-613.

95. Mizoue T, Inoue M, Wakai K, Nagata C, Shimazu T, Tsuji I, Otani T, Tanaka K, Matsuo K, Tamakoshi A, et al: Alcohol drinking and colorectal cancer in Japanese: a pooled analysis of results from five cohort studies. American journal of epidemiology 2008, 167(12):1397-1406.

96. Purohit V, Khalsa J, Serrano J: Mechanisms of alcohol-associated cancers: introduction and summary of the symposium. Alcohol 2005, 35(3):155-160.

97. Seitz HK, Becker P: Alcohol metabolism and cancer risk. Alcohol research \& health: the journal of the National Institute on Alcohol Abuse and Alcoholism 2007, 30(1):38-41, 44-37.

98. Seitz HK, Cho $\mathrm{CH}$ : Contribution of alcohol and tobacco use in gastrointestinal cancer development. Methods Mol Biol 2009, 472:217-241.

99. Frieden TR, Myers JE, Krauskopf MS, Farley TA: A public health approach to winning the war against cancer. The oncologist 2008, 13(12):1306-1313.

100. World Health Organization (WHO): Report on the Global Tobacco Epidemic, 2008: The MPOWER Package In Geneva 2008, 1-329.

101. Norstrom T, Skog OJ: Saturday opening of alcohol retail shops in Sweden: an impact analysis. Journal of studies on alcohol 2003 64(3):393-401.

102. Gruenewald PJ, Remer $L$ : Changes in outlet densities affect violence rates. Alcoholism, clinical and experimental research 2006, 30(7):1184-1193.

103. Gorman DM, Speer PW, Gruenewald PJ, Labouvie EW: Spatial dynamics of alcohol availability, neighborhood structure and violent crime. Journal of studies on alcohol 2001, 62(5):628-636.

104. McGinnis JM, Grootman JA, Kraak Vl: Food Marketing to Children and Youth: Threat or Opportunity? Washington DC: Institute of Medicine, National Academies Press 2006.

doi:10.1186/1471-2482-13-S2-S17

Cite this article as: Rametta et al:: Social disparities, health risk behaviors, and cancer. BMC Surgery 2013 13(Suppl 2):S17. 